\title{
12
}

\section{Regional Solutions for Multi-level Governance Challenges in Australian Coastal and Climate Change Planning}

\section{Barbara Norman and Nicole Gurran}

\section{Introduction}

Australia is one of the most urbanised nations in the world and the location of its urban growth is predominantly in the coastal zone. The 2009 Australian parliamentary report, Managing our Coastal Zone in a Changing Climate: The Time to Act is Now, raised critical issues in relation to managing coastal urban growth in the context of climate change (Australian Parliament 2009; Thom 2010). In particular, it concluded that a more adaptive and systems approach to coastal planning will be required to plan for increasing coastal risk and uncertainty, together with meaningful and ongoing community engagement.

This chapter explores the experience of regional alliances in identifying what strategies could provide the foundations for more sustainable coastal planning and the implications for multi-level governance (DCC 2009; DCCEE 2010; Gurran et al. 2011). With reference to the international literature and research on multi-level governance and climate change policy (e.g. Richardson et al. 2011), the chapter suggests that a national policy framework for sustainable cities and regions should underpin 
long-term regional arrangements for a more sustainable and resilient coastal future. Furthermore, integrated regional planning presents a critical strategic policy instrument for better coordination, integration and implementation in coastal Australia.

The first part of the chapter outlines the policy context surrounding planning for coastal climate change at the national, state and local government levels. Key issues for the coastal communities and the coastal environment include managing urban growth, potential risks and liabilities in response to climate change, financing and governing the transition and a significant gap in skills for implementing a low carbon and more resilient built environment (Norman 2010). The intersection of increased coastal urban growth and the projected impacts of coastal climate change (DCC 2009; Steffen 2009) will require a coordinated response by coastal planning and emergency management to minimise the level of risk to coastal communities (Gurran et al. 2011; Norman 2009).

The establishment of the National Coastal and Climate Change Council in 2010 signalled national recognition of the critical issues involved in sustainable coastal planning (DCCEE 2010). The second part of the chapter discusses this national policy context of managing coastal urban growth and climate change. It discusses the major recommendations of national inquiries and the council, as well as the current policy framework and highlights specific strengths and weaknesses. This is followed by the case for regional-level intervention to tackle the complex or 'wicked' problems associated with overlapping jurisdictional responsibilities, agendas and interests influencing planning and management of the coastal zone.

To address such challenges, and to better connect urban and regional planning, infrastructure development and environmental science, including the impacts of climate change, groups of coastal councils are increasingly forming regional alliances. The third part of the chapter focuses on this regional dimension, which expands beyond a single municipality while remaining closer to the community than higher levels of government (Norman 2010; Smith et al. 2010). The discussion refers to five examples of voluntary regional coastal groupings in different parts of coastal Australia, including the Sydney Coastal Councils Group (SCCG) (a metropolitan coastal region within the nation's largest state capital city, New South Wales), the Peron Naturaliste Partnership (the nine coastal councils on the south coast of Western Australia), the G21 Geelong regional alliance (five councils on the industrial city of Geelong's urban 
edge, Victoria), Dhimurru Sea Country Plan (in remote north-east Arnhem Land, Northern Territory) and South East Coastal Adaptation (SECA, a research collaboration in the increasingly populated area of south-east Australia, far south New South Wales and eastern Victoria). These partnerships/collaborations at the local and regional level are explored to gain a deeper appreciation of the drivers, opportunities and potential barriers to achieving a more sustainable regional approach to urban growth and climate change.

The final section of the chapter will consider the potential contributions of regional planning to managing urban growth and climate change and the implications for multi-governance. Coastal planning is inherently complex, dealing with multi-governance across landscapes in the catchment-to-coast-to-marine continuum. The regional case studies point to some key principles that should underpin more sustainable coastal governance and planning in Australia.

\section{Coastal management: A matter of national interest}

National, state and local levels of government, including community and private sector organisations, are substantially involved in the Australian urban and regional planning system in which coastal management is embedded. This section outlines the key dimensions of coastal management and discusses it in the context of sustainability and climate change. It outlines the key issues in planning for coastal climate change and discusses the implications for the broader outcome of sustainable coasts.

Coastal planning in Australia is primarily based on the concept of integrated coastal management, which is recognised and adopted globally (United Nations, European Commission, South Pacific Forum, the United States and New Zealand). In this chapter, integrated coastal management is defined as:

The integrated planning and management of coastal resources and environments in a manner that is based on the physical socio-economic, and political interconnections both within and among the dynamic coastal systems, which when aggregated together, define a coastal zone (Sorensen 1997). 
All three levels of government in Australia undertake distinct roles in relation to coastal planning and management. The Commonwealth has played an important policy development role, with a series of national-level inquiries since the 1970s drawing attention to the risks of coastal urbanisation: the Australian Advisory Committee on the Environment (AACE 1975), the Standing Committee on Environment and Conservation (1980), and the Resource Assessment Commission (1993). More recently, attention has shifted to the risks associated with climate change in coastal areas, with a significant parliamentary enquiry conducted in 2008 (discussed below).

The federal government has also played an important role in funding support for coastal initiatives, particularly in relation to information such as mapping and coastal data, with a more recent focus on coastal adaptation. Coastal funding programs have included programs such as Caring for our Coasts and Coastal Adaptation Decision Pathways at the regional and local level. The national government, therefore, plays a role of policy development, support and facilitation in coastal planning and management, rather than a direct one of regulation. The Environment Protection and Biodiversity Conservation Act 1999 (EPBC Act) provides a mechanism of referral to the Commonwealth on matters of national environmental significance and has been triggered in the coastal environment. In one of only two EPBC Act refusals, Minister Peter Garrett refused a proposed development of 730 lots in the vicinity of Booderee National Park, Jervis Bay, on the NSW South Coast, because of the impact on nationally listed threatened species and the ecological integrity of the Commonwealth-managed park, which is dependent on connection to surrounding areas via important wildlife corridors (DEWHA 2009). While it is more common for proposals to be amended rather than refused as a result of Commonwealth referral under the EPBC Act, the legislation has added a layer of additional scrutiny to the existing environmental impact assessment processes conducted by the states.

More recently, the federal government has also used the EPBC Act to undertake 'strategic assessments' in high-growth regions across Australia (e.g. Perth and Peel region in Western Australia, and the Great Barrier Reef in far north Queensland). This means that, rather than subjecting individual development proposals to additional environmental impact assessment by the Commonwealth, detailed examination of ecological risks and parameters for development can be undertaken upfront, providing greater clarity for landowners and communities (SEWPAC 2013). Finally, the Regional Development Australia network of 55 committees under the 
Labor governments headed by Kevin Rudd and Julia Gillard required the preparation of regional plans for high-growth coastal regions from Mandurah in Western Australia to south-east Queensland (DRALGAS 2012).

The state and territory governments hold the statutory responsibilities for the development and use of the coastal zone, and these are usually administered through land-use planning legislation or, in some cases, separate coastal management legislation (for instance, the Victorian Coastal Management Act 1995 and the NSW Coastal Protection Act 1979). The state legislation provides the framework and powers for local government action and other relevant public bodies (e.g. regional coastal councils in Victoria) involved in managing the coastal environment (Australian Parliament 2009: Appendix 1). State ministers retain powers on major strategic decisions, such as rezoning of coastal lands from 'greenfield' rural land to urban land available for development, although these actions are often triggered and informed by local government planning processes. Local government is largely responsible for applying the legislation in local planning and development decisions within the policy framework set by higher levels of government. Significant decision-making occurs at the local level, which, although often relatively small in scale, can have a cumulative environmental impact on the coast.

After 2009, the Gillard Government became more active in the development of national coastal policy after being influenced by a series of reports, including Managing our Coastal Zone in a Changing Climate, known as the George Inquiry (Australian Parliament 2009); the report to the minister from the national Coasts and Climate Change Council (2011); the Productivity Commission report Barriers to Effective Climate Change Adaptation (2012); Climate Change Risks to Australia's Coast: A First Pass National Assessment (DCC 2009); and The Critical Decade by the Climate Commission (Steffen and Hughes 2013). During the same period (2009-13), a considerable body of research was undertaken into the impacts of climate change on the coast through the National Climate Change Adaptation Research Facility (e.g. NCCARF 2013; Norman et al. 2013). The Department of Climate Change (DCC 2009) report established some initial baseline data on sealevel rise and implications for coastal vulnerability, paving the way for more detailed work to follow. Research findings included that:

Up to $\$ 63$ billion (replacement value) of existing residential buildings are potentially at risk of inundation from a 1.1 metre sea-level rise, with a lower and upper estimate of risk identified for between 157,000 and 247,600 individual buildings (DCC 2009: 7). 
There have been 25 national inquiries and reports over the last 30 years (Norman 2009), of which the George Inquiry is the latest. This House of Representatives committee report, chaired by the Hon. Jenny George, involved comprehensive engagement of coastal community interests in forming its 47 final recommendations. The recommendations were wideranging and included specific actions on coastal governance, emphasising the need for a national approach: 'One clear message emerged - and that is the need for national leadership in managing our precious coastal zone in the context of climate change' (Australian Parliament 2009: ix).

Other key recommendations emerging from the George Inquiry in relation to coastal governance were that an intergovernmental coastal zone agreement should be established (recommendation 44); a national coastal zone policy and strategy should be adopted, setting out the principles, objectives and actions that must be undertaken to address the challenges of integrated coastal zone management for Australia (recommendation 45); and a national coastal advisory council should be convened (recommendation 46). The committee recommended that the intergovernmental coastal zone agreement should:

- define the roles and responsibilities of the three tiers of government federal, state and local - involved in coastal zone management

- include a formal mechanism for community consultation; incorporate principles based on strategic regional coastal planning and landscapescale/ecosystem-based coastal zone management

- include an effective implementation plan with resources allocated to ensure that objectives are realised

- be overseen by a new coastal zone ministerial council

- be made public (recommendation 44: 290).

Following the George Inquiry report, the national Coasts and Climate Change Council established in late 2009 (initially chaired by renowned scientist Tim Flannery, followed by coastal management expert Bruce Thom) reported to the minister for climate change and provided two reports during its two-year term: an interim report in December 2010 and a final report in December 2011. In its final report, the council made recommendations in five key areas for action on climate change adaptation: 1) climate-risk protection to guide planning and investment, 2) improving decision-making through better science and information, 3) coastal policy and regulatory reform, 4) on-ground adaptation tackling 'hotspots', and 
5) integrating climate change into national agendas. The council also commissioned an important report on the legal implications arising from coastal climate change (Gibbs and Hill 2011).

During 2011, the Gillard Government also established a Climate Change Select Committee comprising ministerial representatives of the states and the Northern Territory. A particular focus was to outline the roles and responsibilities for all three levels of government and the private sector in relation to climate adaptation, as follows:

The basic principle of the management of climate change risk should be as follows:

Private parties should be responsible for managing risks to private assets and incomes. Governments - on behalf of the community - should primarily be responsible for managing risks to public goods and assets (including the natural environment) and Government service delivery and creating an institutional, market and regulatory environment that supports and promotes private adaptation (Select Council on Climate Change 16 November 2012).

The Select Committee concluded that the federal government's role is to 'provide national science and information; manage Commonwealth assets and programs; provide leadership on national adaptation reform; maintain a strong, flexible economy and a well-targeted social safety net' (Select Committee of Climate Change 2012: 1-3). The state and territory roles are much the same but, at the sub-national level, they have a focus on 'encouraging climate resilience and adaptive capacity'. Local government generally focuses on regional and local impacts and ensuring climate change is considered in decision-making (Select Committee of Climate Change 2012: 3-6).

Despite the above national reports and recommendations, more recent evidence suggests a 'winding back' of environment and planning policy on coasts and climate change at the sub-national level. During 2012/13, the Queensland state 'suspended' its coastal plan, the NSW Government devolved its sea-level rise policies back to local government and announced the end of catchment management, and the Victorian Government softened planning regulations (Norman 2013). The rhetoric of 'cutting the green tape' emerged and grew stronger during the 2013 federal election campaign. To add to the mix, the Australian Local Government Association at its 2013 general assembly resolved: 
That the National General Assembly call on the Australian Government to initiate a coordinated national approach, involving all three levels of Government, for planning and managing the Australian Coast for the benefit of future generations (ALGA 2013).

Despite this fairly extensive national-level policy framework to support climate change adaptation in coastal areas, actual progress at the local scale has been patchy at best (Gurran et al. 2013). A practice audit (involving an internet survey, in-depth interviews and focus groups with planners and councillors) from 47 coastal councils of non-metropolitan Australia found high levels of awareness about climate risks to their communities, particularly in relation to sea-level rise, shoreline loss, storm surge and coastal erosion, and concern that development continues in vulnerable locations, exacerbating future risk. Study participants also reported levels of community anxiety about climate risk. As well as storm surge and inundation, new risks associated with changed climatic conditions, such as increased likelihood of bushfires, concerned local residents. Respondents were also aware of a level of resident anxiety about the impact of perceived climate effects and associated development restrictions on property values.

Despite this evident awareness of, and concern for, climate risks, few local councils have moved far beyond the stage of vulnerability assessment, although many had begun the process of updating infrastructure and asset management strategies, and revising planning controls. This work depends on local political support, with some councils in the study undertaking no climate-related action at all, while others, such as the Cairns City Council in far north Queensland and Lake Macquarie in New South Wales, have developed comprehensive frameworks for climate change adaptation. Councils that have begun to move forward on climate adaptation typically received funding support from Commonwealth or state sources. Such funding is usually provided on a competitive basis, rather than allocated to all coastal councils on the basis of climate risk and need for assistance. Therefore, in reviewing levels of progress towards climate adaptation, a strong bias towards larger, better-resourced councils, governed by committed political leaders, was apparent.

Even these councils, however, reported difficulties associated with gaining community acceptance of the need for action, with some wealthy property owners prepared to mount expensive challenges to preserve development entitlements and to enact private defensive measures, such as seawalls. Others described increasing 'push back' from climate sceptics. 
Overall, there was strong criticism for perceived weaknesses in state policy and laws, aside from the identification of sea-level rise benchmarks for land-use planning purposes in most states. Victoria, South Australia, New South Wales, Queensland and Western Australia all had benchmarks at the time the study was carried out, although New South Wales has subsequently amended policy in favour of voluntary local determination. Regulations and development controls governing inundation, building and infrastructure standards for climate resilience were all regarded as inadequate by respondents. Furthermore, new work to improve local planning frameworks was stymied by a lack of reliable and fine-grained spatial data and insufficient resources to commission the necessary studies. This has become a particular issue in New South Wales, where the rescinding of state-mandated sea-level rise benchmarks places the onus on local councils to develop thresholds for planning purposes.

In summary, federal government leadership in the governance of Australia's coastal zone is elusive. As outlined above, there has been a consistent call for a national coastal policy on coastal planning and management to provide a framework for decision-making at the sub-national, regional and local levels. This has been supported by further nationally funded research in the context of climate change. The evidence also indicates, however, that despite national interest, action on coastal management and climate change at the state and local level is unchanged or in some cases diminishing. The only sustained area of activity appears to be at the regional level through voluntary collaboration, as discussed below.

\section{Regional collaborations for more sustainable coasts}

Regional organisations have long been part of Australian coastal governance. Statutory regional coastal planning authorities of the 1970s, such as the Westernport Regional Planning Authority and the Geelong Regional Commission, provided significant coastal protection measures for coastal lands facing development. The 1990s saw various iterations of regional coastal and catchment committees with a strong emphasis on collaboration (for example, within Victoria and NSW) and, more recently, the nesting of regional coastal plans in the planning system (Western Australia). This section discusses five voluntary regional collaborations involving a range of stakeholders in different parts of the Australian coastline: 
- Sydney Coastal Councils - a coastal alliance of 15 urban councils within Australia's largest capital city in New South Wales

- Peron Naturaliste Partnership - a coastal alliance of nine coastal councils on the south coast of regional Western Australia

- G21 Geelong regional alliance - a coastal alliance of five councils on the urban edge of an expanding metropolis in Victoria

- Dhimurru Sea Country Plan - a coastal alliance of Indigenous land owners in north-east Arnhem Land, Northern Territory

- South East Coastal Adaptation - a research collaboration involving local and regional organisations in south-east Australia involving two states (NSW and Victoria).

These case studies explore regional collaboration across a range of coastal landscapes and jurisdictions, providing insight into emerging responses to coastal planning and management in Australia. Information is drawn from a synthesis of material previously published by the authors and additional primary fieldwork (Norman 2009; Gurran et al. 2008, 2013). The discussion here is not intended to be comprehensive but, rather, to highlight leading practice models in relation to a range of regional partnerships, providing insights into their formation and implications for future coastal governance.

\section{Sydney Coastal Councils Group}

The Sydney Coastal Councils Group Inc. (SCCG) is an alliance of 15 coastal councils that has been running since 1989. Established under the Local Government Act 1993, its councils flank coast and estuaries north and south of Sydney. The SCCG has developed over time into an effective voice for coastal concerns supported by a considerable body of research (Smith et al. 2008; SCCG 2012). The mission of the SCCG is 'to provide leadership through a coordinated approach to sustainable coastal management' and the aim is 'to promote cooperation between, and coordination of actions by, Member Councils on issues of regional significance concerning the sustainable management of the urban coastal environment' (SCCG 2013: 1). SCCG represents a coastal alliance surrounding a major capital city facing urban growth pressures and large investment decisions on urban-coastal infrastructure, including the location of new airports. 
The governance structure of the SCCG is that of a voluntary organisation and is managed by representatives from member councils supported by a smaller executive group and technical and working groups (SCCG 2011). Funding is provided by council contributions based on a flat rate plus 'a further supplementary contribution, calculated on a population basis for each member council' (SCCG 2011: 16.3). The SCCG Strategic Plan 2010-14 outlines the 'guiding principles' for this alliance:

- protection of the environment and cultural values

- integrated planning and decision-making

- sustainable use of natural coastal resources

- appropriate and meaningful public participation (SCCG 2010: 12).

Over 23 years, the SCCG has delivered significant outcomes, including dealing with storm water run-off, protecting Sydney's wetlands, coastal management and sand nourishment. More recent projects have included regional climate change adaptation strategies, community involvement programs and decision-making frameworks for seawall structures (SCCG 2013). Its longevity in continuing as an organisation, involving several councils with diverse agendas, is a hallmark of the SCCG strength as a model of regional collaboration.

\section{Peron Naturaliste Partnership - a west coast regional partnership}

The vision of the Peron Naturaliste Partnership is to empower a resilient regional community to reduce risks and optimize opportunities presented by climate change (PNP 2013a: 3).

The Peron Naturaliste Partnership (PNP) is a regional collaboration between nine local councils in south-west Western Australia (Bunbury, Busselton, Capel, Dardanup, Harvey, Mandurah, Murray, Rockingham and Waroona). This covers the coastal region from Cape Peron to Cape Naturaliste. The governance arrangements for this regional initiative rest in a voluntary memorandum of agreement (2011, updated 2013-15). The objectives of the partnership are to:

- demonstrate regional leadership to support effective advocacy at all levels of government;

- facilitate access to data and information relevant to the Peron Naturaliste coast, including estuarine areas 
- adopt a regional approach to the preparation of applications for grants and other submissions to support timely adaptation responses to climate change

- promote consistent information to coastal communities and decisionmakers about vulnerability and risk and adaptation strategies

- share local knowledge and experience to support and inform innovative and effective adaptation responses

- collaborate over the management implications of the risk to life and property caused by climate change

- identify and address current and potential coastal including estuarine hazards through research and project development (PNP 2013a: 3).

The focus is on regional leadership, access and sharing of data and knowledge, collaboration over funding initiatives and managing risk to people and place. It is a voluntary non-binding agreement to work together on complex coastal issues in the context of climate change.

The motivation to collaborate in this region stemmed from the initial findings in the Department of Climate Change's first pass assessment report (DCC 2009) that indicated that the coastline in the PNP region contained over 60 per cent of residential buildings at risk from coastal inundation in Western Australia, with an estimated replacement value ranging between $\$ 2.9$ billion and $\$ 4.62$ billion (DCC 2009: 115; PNP 2013a: 4). Following this, preliminary research that was funded by all three levels of government indicated that, until 2100 in the Peron Naturaliste region, 'erosion is a far more pervasive issue than flooding' (DCC 2009). Around 800 hectares of urban and commercial land are thought to be at risk of increased flooding, and erosion threatens a 200-metre-wide strip along much of the coastline. In economic terms, assets likely to be lost amount to approximately $\$ 1.2$ billion in value, while around $\$ 1.1$ billion could be protected at an estimated cost of $\$ 120$ million (PNP 2013b: 4).

The PNP is funded by contributions from each council on the basis of rates and employs two part-time officers located at Mandurah City Council. The partnership's business plan outlines short-, medium- and long-term goals that will facilitate knowledge and communication to reduce risk to communities and the environment. The emphasis for the PNP in 2013-15 was on communications to build awareness and understanding in the regional community on the risks from climate change and pathways forward. 


\section{G21 Geelong regional alliance}

G21 is a platform for the councils to engage with business, industry, state and federal government and other agencies on issues of mutual benefit to the region (G21 2013b: 1).

The G21 Geelong regional alliance was established as a community initiative calling for more regional cooperation on matters of mutual interest to five local government areas (Geelong, Colac, Golden Plains, Queenscliff and Surf Coast). The Geelong region has a significant history of active regional organisations dating back to the 1970s. G21 commenced from a community meeting during 2002 and has grown to be a strong regional organisation recognised and supported by all three levels of government (Norman 2009).

G21 is a local government alliance that flanks the south-west coast east of Geelong. It comprises members from four coastal councils and one inland neighbouring council and it is governed by representatives appointed from those councils and elected representatives from its wider membership. G21 is different from a local government alliance in that its membership is diverse and open to statutory authorities, proprietary companies, public companies, local government, cooperatives, incorporated associations, state government departments and authorities, and federal government departments and authorities (G21 2012: 4).

The G21 organises itself around eight 'pillars' - sport and recreation, environment, transport, health and wellbeing, planning and services, education and training, economic development and arts and culture (G21 2012: 6-7). These pillars are underpinned by the G21 Regional Plan, which articulates five key directions: Direction 1 - Protection and Enhance Our Environment, Direction 2 - Create Sustainable Settlements, Direction 3 - Strengthening our Communities, Direction 4 - Refocus our Economy, and Direction 5 - Collaborating to Make it Happen (G21 2013a: 5).

G21 is different from the other regional alliances discussed here because it has a wider focus than the immediate coastline and a more comprehensive regional approach to policy initiatives and actions. This regional collaboration has been particularly successful in identifying priorities for the region derived from its regional plan and subsequently attracting major funding from all levels of government for implementing its program. It appears likely that the collaboration's triple bottom line approach and collaborative governance arrangements underpin its long-run and continuing success. G21 builds on 
a lineage of regional plans for Geelong region, using 'regional planning' as the tool for integrating a wide range of considerations in managing the multiple pressures facing a large, growing coastal region.

\section{Dhimurru Yolnuwu Monuk Gapu Wäna - Sea Country Plan, north-east Arnhem Land}

This plan is an opportunity for us to speak for our sea country in our own way and to do this at a scale that is culturally and geographically appropriate. Our plan provides the framework for a detailed dialogue with the other main stakeholders in Yolnu Sea Country. We look forward to this discussion and exploring ways of implementing this plan to manage Yolnu Sea Country (Dhimurru 2006: 17).

The north coast of Australia is now largely managed by Aboriginal land councils. Yolyuwu Monuk Gapu Wäna Sea Country Plan: A Yolyu Vision and Plan for Sea Country Management in North-east Arnhem Land, Northern Territory (Dhimurru 2006; DEWHA 2008) is an integrated coastal plan that represents a regional approach by traditional owners to managing 'sea country', which is defined as both land and sea. The approach is similar to G21 in using a strategic coastal plan to provide the framework for decision-making that respects traditional and community values. It expresses the vision and a plan for the sea country and is underpinned by seven principles that are based on rights, transparent and adaptive decision-making processes and long-term sustainability:

Seven Yolyu principles for managing sea country:

1. We have a basic right and central right to maintain our traditional ownership and management of our sea country using both our traditions and the tools and practices available to us as citizens of contemporary Australia.

2. We are interested in the long-term benefit of our sea country to Yolyu people. We are interested in making sure that conservation and management of our sea country brings long-term human wellbeing and benefit to Yolyu people and to other users who have interests and values there. That is, they believe in and practise cultural, ecological, social and economic sustainability.

3. We are interested in everybody being clear and transparent about their rights and responsibilities to our sea country.

4. The best way to conserve and manage our sea country is by drawing on the Yolyu customary and contemporary knowledge traditions. 
5. We need to build on our knowledge of sea country and life forms if we are to manage them sustainably.

6. We should err on the side of caution when considering proposals and options for use of our sea country, especially in the absence of a full understanding of their risks and consequences.

7. We will need to be flexible and adaptable in our responses to caring for and managing our sea country, especially in a world where circumstances can change rapidly (Dhimurru 2006: 11-12).

The principles above also incorporate a precautionary approach to coastal management in the face of environmental risks and recognise that coastal land and waters are a continuum that require an integrated approach to planning and management. Most importantly, the principles provide a possible guide to leading practice in 'collaboration' for environmental management (Hoffman et al. 2012).

\section{South East Coastal Adaptation - a coastal regional research alliance}

What is evident is that to be climate-adapted, a community requires effective planning, decision-making and implementation of responses to current and emerging climate change impacts and risks - effective governance with an adaptive decision-making process to planning for climate change (Norman et al. 2013: 4).

The South East Coastal Adaptation (SECA) alliance is a more recent collaboration between three universities (University of Canberra, The Australian National University and University of Wollongong). During 2012/13, a national research project, Coastal Urban Climate Futures in south-east Australia from Wollongong to Lakes Entrance, was undertaken involving regional organisations and relevant local councils. The focus of the research was coastal adaptation. An interdisciplinary team examined coastal urban futures in the context of sustainability and climate change. This regional collaboration builds on a wider regional initiative, Canberra Urban and Regional Futures (CURF) (Norman and Steffen 2011).

A key outcome of the research was the development of seven key principles, devised specifically for coastal towns facing climate change in south-east Australia, but which might resonate more widely: 
1. an integrated approach should be adopted for sustainable regional and local planning (social, economic, environmental and cultural)

2. a precautionary principle should be applied to decision-making regarding the location of new and redeveloped urban settlement and infrastructure and other relevant decisions

3. risk management approaches should be incorporated into local and regional strategies for coastal settlements

4. appropriate forums should be established at the regional level to enable collaboration

5. there should be an ongoing process of community engagement

6. the skills and knowledge of regional and local communities should be connected

7. a process of continuing monitoring, evaluation and reporting of adaptation actions should be implemented (summary of Norman et al. 2013: 7).

The research also concluded that a collaborative intergovernmental approach was fundamental to a 'well adapted' community in the future. This is consistent with the key governance recommendations of the George Report, discussed earlier. In other words, the process of decision-making is critical in determining how a community adapts to change (social, economic and environmental). Support and coordination from higher levels is important to ensure that there is a consistent approach to decisions for multi-use coastal zones. It is interesting that the seven principles developed in two separate processes - Yolyu people in north-east Arnhem land and on the south-east coast New South Wales and Victoria - share approaches to adaptive decision-making processes, take a long-term view, adopt a precautionary approach and a confirm commitment to sharing knowledge.

The SECA collaboration continues under the umbrella of CURF, strengthening partnerships between coastal planning and environmental science and a further collaboration with the ANU School of Art field studies program. This has provided a platform for long-term collaboration on coastal planning and management with regional and local coastal communities in south-east Australia. 


\section{National collaborative coastal alliances}

The National Sea Change Taskforce (NSTF) was established in response to rapid growth of coastal towns. ${ }^{1}$ It is a coalition of coastal local governments concerned with the impacts of growth pressures and consequent demands on infrastructure and services. The taskforce has also been concerned with the impacts of climate change on coastal environments (Gurran et al. 2008, 2011). During April 2006, the taskforce launched a Sustainability Charter - A Collaborative National Response to Sea Change Growth (NSTF 2006). The charter aimed to gain support from federal, state and local governments for more sustainable coastal planning that considers social, economic and environmental impacts; to develop innovative and best practice strategic planning at regional and local levels; to preserve local character and sense of place; for the timely provision of resources to meet the needs of highgrowth communities for infrastructure and services; to integrate coastal management and conservation objectives with economic development; to support community wellbeing; and to ensure community ownership and participation in key planning decisions affecting the coast (NSTF 2006: 1).

The taskforce has built on this charter through an annual national conference, by commissioned research to inform its policy development and via regular representations to government on the pressures facing coastal communities.

In the context of a looming federal election in 2013, the taskforce joined with allied groups to form the Australian Coastal Advocacy Alliance (ACAA) to advocate for a more coordinated approach to coastal planning in Australia. This groundswell of coastal interests builds on the formative work of the taskforce and presents a considerable coastal coalition with an agreed mandate from local councils and communities. The inaugural membership comprised the NSTF, Association of Bayside Municipalities (Victoria), Australian Coastal Society, Metropolitan Seaside Councils Committee (South Australia), Queensland Regional Natural Resource Management Groups Collective, Surf Life Saving Australia, Surfrider Foundation and SCCG. The ACAA is focused on three key platforms:

a collaborative national response to coastal planning and management involving all three tiers of government; an intergovernmental agreement defining the roles and responsibilities of each tier of government in

1 The National Sea Change Taskforce has now reformed as the Australian Coastal Council Alliance. 
relation to the coastal zone; and a national coastal policy that addresses the challenges facing the coast zone through a national coastal commission and accompanying Act (ACAA 2013a).

The ACAA policy platform reflects the key elements of the George Report and the key messages from the regional collaborations and coastal research discussed above - coordination, collaboration and the engagement of all levels of government are critical to effective integrated coastal management. The ACAA actively lobbied the key political parties during the 2013 federal election for support for a national coastal policy (ACAA 2013b).

\section{Discussion}

The collaborative regional alliances outlined in this chapter have developed in a range of coastal landscapes and demonstrate potential foundations for more sustainable and integrated coastal planning and management. They point to a series of important principles for coastal governance at regional and local levels, including respect for local and Indigenous Australian knowledge, a focus on adaptation to future climate risk, integrated management across the land and sea continuum, transparency in decision-making and ongoing application of the precautionary principle. In short, despite the continuing gap between the projected impacts of climate change on Australian coasts and action at the state and local level, regional organisations are becoming an important and effective governance mechanism for coastal management for regions experiencing global and climate change.

Table 12.1 highlights some key governance characteristics shared by the case studies. Voluntary collaboration is a common characteristic that is often supported by some form of contract, such as a memorandum of understanding. It is difficult to conclude whether the 'voluntary' nature is by choice or simply a response to the absence of a more formal structure or both. It is clear, however, that these alliances have delivered some leading practice in coastal planning and management throughout Australia. The second key characteristic is the apparent preparedness of local councils to work together on critical issues that cross local government boundaries - in this case, regional climate change and coastal change. This includes local councils on the west, north, south and east coast. The third key characteristic is that there is no long-term security to funding, which is dependent on continuing contributions by participants. This places a heavy reliance on a continuing long-term commitment to a shared interest beyond short-term politics. 
Table 12.1: Governance of regional coastal collaborations

\begin{tabular}{|c|c|c|c|c|}
\hline Case study & Organisation & Membership & Funding & Outcomes \\
\hline $\begin{array}{l}\text { Sydney } \\
\text { Coastal } \\
\text { Councils } \\
\text { Group } \\
\text { (NSW) }\end{array}$ & $\begin{array}{l}\text { Voluntary } \\
\text { alliance } \\
\text { governed by } \\
\text { a constitution }\end{array}$ & $\begin{array}{l}15 \text { local coastal } \\
\text { councils }\end{array}$ & $\begin{array}{l}\text { Local council } \\
\text { members }\end{array}$ & $\begin{array}{l}\text { Coastal } \\
\text { management, } \\
\text { regional climate } \\
\text { change and sand } \\
\text { nourishment }\end{array}$ \\
\hline $\begin{array}{l}\text { Peron } \\
\text { Naturaliste } \\
\text { Partnership } \\
\text { (WA) }\end{array}$ & $\begin{array}{l}\text { Voluntary } \\
\text { alliance } \\
\text { established } \\
\text { through a } \\
\text { memorandum } \\
\text { of understanding }\end{array}$ & $\begin{array}{l}\text { Nine local } \\
\text { coastal councils }\end{array}$ & $\begin{array}{l}\text { Local council } \\
\text { members }\end{array}$ & $\begin{array}{l}\text { Regional } \\
\text { leadership, } \\
\text { economic impact } \\
\text { of climate change, } \\
\text { community } \\
\text { awareness }\end{array}$ \\
\hline $\begin{array}{l}\text { G21 } \\
\text { Geelong } \\
\text { regional } \\
\text { alliance }\end{array}$ & $\begin{array}{l}\text { Voluntary } \\
\text { alliance } \\
\text { governed by } \\
\text { a constitution }\end{array}$ & $\begin{array}{l}\text { Five local } \\
\text { councils } \\
\text { and elected } \\
\text { members } \\
\text { from wider } \\
\text { membership }\end{array}$ & $\begin{array}{l}\text { Local council } \\
\text { members }\end{array}$ & $\begin{array}{l}\text { G21 regional } \\
\text { plan, significant } \\
\text { government } \\
\text { grants, wide } \\
\text { support from } \\
\text { government and } \\
\text { industry } \\
\end{array}$ \\
\hline $\begin{array}{l}\text { Dhimurru } \\
\text { (NT) }\end{array}$ & $\begin{array}{l}\text { Community- } \\
\text { based Dhimurru } \\
\text { Aboriginal } \\
\text { Corporation } \\
\text { (north-east } \\
\text { Arnhem Land) }\end{array}$ & $\begin{array}{l}\text { Clans with } \\
\text { estates and } \\
\text { interests in } \\
\text { the Dhimurru } \\
\text { Indigenous } \\
\text { Protected Area } \\
\text { (IPA) }\end{array}$ & $\begin{array}{l}\text { Wide range of } \\
\text { government } \\
\text { and research } \\
\text { organisations } \\
\text { and related } \\
\text { industries }\end{array}$ & $\begin{array}{l}\text { Implementing the } \\
\text { Dhimurru Sea } \\
\text { Country Plan } \\
\text { (seven principles), } \\
\text { undertaking } \\
\text { coastal and marine } \\
\text { management and } \\
\text { research }\end{array}$ \\
\hline $\begin{array}{l}\text { SECA } \\
\text { (NSW and } \\
\text { Vic) }\end{array}$ & $\begin{array}{l}\text { Voluntary } \\
\text { research } \\
\text { and policy } \\
\text { collaboration }\end{array}$ & $\begin{array}{l}\text { University of } \\
\text { Canberra, } \\
\text { The Australian } \\
\text { National } \\
\text { University, } \\
\text { University of } \\
\text { Wollongong } \\
\text { collaborating } \\
\text { with seven local } \\
\text { coastal councils }\end{array}$ & \begin{tabular}{|l|} 
Universities, \\
research \\
organisations, \\
public \\
agencies \\
and related \\
industries
\end{tabular} & $\begin{array}{l}\text { Coastal adaptation } \\
\text { research (seven } \\
\text { principles), } \\
\text { community } \\
\text { engagement on } \\
\text { climate change, } \\
\text { education }\end{array}$ \\
\hline
\end{tabular}

The impacts of climate change will be significant in Australia (IPCC 2014). The extent of these impacts may mean shifting from incremental change to transformational adaptation with implications for institutional and governance arrangements; for example, no development in high-risk coastal areas. The case studies discussed in this chapter provide an insight into some of the governance characteristics of regional alliances and the organic nature of their resilience as organisations facing complex issues of environmental change. 


\section{Conclusion}

This chapter focuses on the multi-governance challenge of integrated coastal management around Australia and its application by governments in different jurisdictions. Despite a plethora of national- and statelevel coastal inquiries and reports over 40 years since the mid-1970s, Australia still lacks a national coastal policy. National-level efforts have, however, undoubtedly informed, and in some cases propelled, activities at lower levels of government. In particular, regional collaboration has provided a mechanism for cutting across jurisdictional boundaries and facilitating innovation. The largely voluntary nature of the collaborations is considered a strength, in contrast with the more rigid nature of the three-tiered federal system, but it also potentially exposes the models to risk if resourcing is reduced.

Managing the long-term environmental sustainability of the Australian coast is a complex multi-governance challenge. Urban growth, the influence of demographic and global change and the impacts of climate change will only increase the pressures on our coastal environment and communities. Regional collaboration, if supported by Commonwealth and state governments, may offer a positive pathway towards an integrated approach for more sustainable coasts in the context of climate change.

\section{References}

AACE (1975). Coastal Land. Australian Advisory Committee on the Environment, Australian Government Publishing Service, Canberra.

ACAA (2013a). National Coastal Policy Initiative. Australian Coastal Advocacy Alliance, coastalcouncils.org.au/ [Accessed: 23/12/2014].

- (2013b). Support for a National Coastal Policy. Letter to Federal Secretary of the Liberal Party of Australia, 7 August. Australian Coastal Advocacy Alliance.

ALGA (2013). Resolutions from the 2013 National General Assembly of Local Government, 16-19 June. Australian Local Government Association, alga.asn.au/site/misc/alga/downloads/events/2013NGA/ Resolutions2013.pdf [Accessed: 21/12/2014]. 
Australian Parliament (2009). Managing our Coastal Zone in a Changing Climate - The Time to Act is Now. House of Representatives Standing Committee on Climate Change, Water, Environment and the Arts, Canberra.

Coasts and Climate Change Council (2011). Summary of Council Recommendations to the Australian Government. Department of Industry, Innovation, Climate Change, Science, Research and Tertiary Education, Canberra.

DCC (2009). Climate Change Risks to Australia's Coast: A First Pass National Assessment. Department of Climate Change, Australian Government, Canberra.

DCCEE (2010). Developing a National Coastal Aadaptation Agenda: A Report on the National Coastal Climate Change Forum. Department of Climate Change and Energy Efficiency, Canberra.

DEWHA (2008). Dhimurru Arnhem Land Northern Territory. Department of Environment, Water, Heritage and the Arts, Canberra.

- - (2009). Decision to Refuse Action, Heritage Estates Rezoning and Public Infrastructure Works. Facilitating Development of 730 Lots, Worrowing Heights, NSW (EPBC 2007/3448). Department of Environment, Water, Heritage and the Arts, Canberra.

Dhimurru (2006). Yolyuwu Monuk Gapu Wäna Sea Country Plan: A Yolyu Vision and Plan for Sea Country Management in North-east Arnhem Land, Northern Territory. Dhimurru Land Management Aboriginal Corporation, Nhulunbuy, Northern Territory.

DRALGAS (2012). Annual Report 2011-02. Department of Regional Australia, Local Government, Arts and Sport, Canberra.

G21 (2012). Report to the Region 2012, www.g21.com.au/g21-reportregion-2012 [Accessed: 9/11/2017].

. (2013a). Priority Projects G21 Regional Plan Implementation, www. g21.com.au/priority-projects [Accessed: 9/11/2017].

—_. (2013b). The G21 Municipalities, www.g21.com.au/g21municipalities [Accessed: 24/8/2013]. 
Gibbs, M. \& Hill, T. (2011). Coastal Climate Change Risk - Legal and Policy Responses in Australia. Report prepared for the Department of Climate Change and Energy Efficiency, Commonwealth of Australia, Canberra.

Gurran, N., Hamin, E. \& Norman, B. (2008). Planningfor Climate Change: Leading Practice Principles and Models for Sea Change Communities in Coastal Australia. Prepared for the National Sea Change Taskforce, Planning Research Centre, University of Sydney.

Gurran, N., Norman, B., Gilbert, C. \& Hamin, E. (2011). Planning for Climate Change Adaptation in Coastal Australia: State of Practice. Report No. 4 for the National Sea Change Taskforce, Faculty of Architecture, Design and Planning, University of Sydney.

Gurran, N., Norman, B. \& Hamin, E. (2013). Climate Change Adaptation in Coastal Australia: An audit of planning practice. Ocean \& Coastal Management, 86: 100-09. doi.org/10.1016/j.ocecoaman.2012.10.014

Hoffmann, B.D., Roeger, S., Wise, P., Dermer, J., Yunupingu, B., Lacey, D., Yunupingu, D., Marika, B., Marika, M. \& Panton, B. (2012). Achieving Highly Successful Multiple Agency Collaborations in a Cross-Cultural Environment: Experiences and lessons from Dhimurru Aboriginal Corporation and partners. Ecological Management and Restoration, 13(1): 42-50. doi.org/10.1111/j.14428903.2011.00630.x

IPCC (2014). Working Group II(WGII) Contribution to the Fifth Assessment Report on Impacts, Adaptation and Vulnerability. Intergovernmental Panel on Climate Change, Yokohama, Japan, 31 March 2014.

NCCARF (2013). National Climate Change Adaptation Research Facility. Griffith University, Queensland, www.nccarf.edu.au [Accessed: 23/12/2014].

Norman, B. (2009). Principles for an intergovernmental agreement for coastal planning and climate change in Australia. Habitat International, 33(3): 293-99. doi.org/10.1016/j.habitatint.2008.10.002

- (2010). Sustainable Coastal Planning for Urban Growth and Climate Change. NSW Coastal Conference, Batemans Bay.

- (2013). Smart planning for urban growth can minimise flood risks. The Drum, ABC, 31 January 2013, www.abc.net.au/ unleashed/4492512.html [Accessed: 23/12/2014]. 
Norman, B. \& Steffen, W. (2011). Canberra Urban \& Regional Futures An Innovative Regional Platform for Building Resilience. CURF paper no. 1, Canberra.

Norman, B., Steffen, W., Webb, R., Capon, A., Maher, W., Woodroffe, C., Rogers, K., Tanton, R., Viddyattama, Y., Lavis, J., Sinclair, H. \& Weir, B. (2013). South East Coastal Adaptation (SECA): Coastal urban climate futures in SE Australia from Wollongong to Lakes Entrance. National Climate Change Adaptation Research Facility, Gold Coast, pp. 130.

NSTF (2006). Sustainability Charter - A Collaborative National Response to Sea Change Growth. National Sea Change Taskforce, Sydney, coastalcouncils.org.au/

PNP (2013a). Business Plan 2013-2015. Peron Naturaliste Partnership, Mandurah, WA.

—_. (2013b). Coastal Adaptation Decision Pathways Project, Developing Flexible Adaptation Pathways for the Peron Naturaliste Coastal Region of WA. Peron Naturaliste Partnership, Mandurah, WA.

Productivity Commission (2012). Barriers to Effective Climate Change Adaptation. Report 59. Final Inquiry Report, Canberra.

Resource Assessment Commission (1993). Coastal Zone Inquiry: Final Report Overview. Australian Government, Canberra.

Richardson, K., Steffen, W. \& Liverman, D. (eds) (2011). Climate Change: Global Risks, Challenges and Decisions. Cambridge University Press.

SCCG (2010). Strategic Plan 2010-2014. Sydney Coastal Councils Group.

—_. (2011). Constitution. Sydney Coastal Councils Group.

- - (2012). Prioritising Coastal Adaptation Development Options for Local Development, Project Summary Report. Sydney Coastal Councils Group.

- - (2013). About the Sydney Coastal Councils Group, www.sydney coastalcouncils.com.au/About_SCCG [Accessed: 23/12/2014]. 
Select Council on Climate Change (2012). Roles and Responsibilities for Climate Change in Australia. Paper released at the second meeting of the Select Council on Climate Change, 16 November 2012, Canberra.

SEWPAC (2013). Strategic Assessments. Department of Sustainability, Environment, Water, Population and Communities, Canberra, www. environment.gov.au/epbc/assessments/strategic.html [Accessed: 23/12/2014].

Smith, I., Dodson, J., Gleeson, B. \& Burton, P. (2010). Growing Adaptively: Responding to Climate Change through Regional Spatial Planning in England and Australia. Urban Research Program, Research Paper 31, Griffith University, Brisbane.

Smith, T., Brooke, C., Measham, T., Preston, B., Gorddard, R., Withycombe, G., Beveridge, B. \& Morrison, C. (2008). Case Studies of Adaptive Capacity: Systems Approach to Regional Climate Change Adaptation Strategies in Metropolises. University of Sunshine Coast, CSIRO Marine and Atmospheric Research, CSIRO Sustainable Ecosystems, WWF Australia, Sydney Coastal Councils Group, Sydney.

Sorensen, J. (1997). National and International Efforts at Integrated Coastal Management: Definitions, achievements, and lessons. Coastal management, 25(1): 3-41. doi.org/10.1080/08920759709362308

Standing Committee on Environment and Conservation (1980). Australian Coastal Zone Management. Report from the House of Representatives Standing Committee on Environment and Conservation. March 1980, Australian Government Publishing Service, Canberra.

Steffen, W. (2009). Climate Change 2009 - Faster Change and More Serious Risks. Prepared for the Department of Climate Change, Canberra.

Steffen, W. \& Hughes, L. (2013). The Critical Decade: Climate Change Science, Risks and Response. Report for the Climate Commission. Department of Industry, Innovation, Climate Change, Science, Research and Tertiary Education, Canberra.

Thom, B. (2010). National Coastal Reform-2010 and Beyond. Keynote speech to the National Coastal Conference, Adelaide. 
This text is taken from Multi-level Governance: Conceptual challenges and case studies from Australia, edited by Katherine A. Daniell and Adrian Kay, published 2017 by ANU Press, The Australian National University, Canberra, Australia.

dx.doi.org/10.22459/MG.11.2017.12 